\title{
Purification and characterization of a ferulic acid esterase (FAE-III) from Aspergillus niger: specificity for the phenolic moiety and binding to microcrystalline cellulose
}

\author{
Craig B. Faulds and Gary Williamson
}

Department of Food Molecular Biochemistry, AFRC Institute of Food Research, Norwich Laboratory, Norwich Research Park, Colney, Norwich NR4 7UA, UK
Author for correspondence: Gary Williamson. Tel: + 44603 255259. Fax : + 44603507723.

An inducible ferulic acid esterase (FAE-III) has been isolated, purified and partially characterized from Aspergillus niger after growth on oat spelt xylan. The purification procedure utilized ammonium sulphate precipitation, hydrophobic interaction and anion-exchange chromatography. The purified enzyme appeared almost pure by SDS-PAGE, with an apparent $M_{r}$ of 36000 . A single band, corresponding to a pl of 3.3 was observed on isoelectric focusing. With methyl ferulate as substrate, the enzyme had a specific activity of $67 \mathrm{IU}$ ( $\mathrm{mg}$ protein $)^{-1}, \mathrm{pH}$ and temperature optima of 5 and 55-60 ${ }^{\circ} \mathrm{C}$, respectively, and a $K_{\mathrm{m}}$ of $2.08 \mathrm{mM}$ and a $V_{\max }$ of $175 \mu \mathrm{mol} \mathrm{min}^{-1}\left(\mathrm{mg} \mathrm{protein}^{-1}\right.$. The enzyme was also active upon methyl sinapinate, methyl-3,4-dimethoxy cinnamate and methyl p-coumarate, but not benzoic acid methyl esters or methyl caffeate. Similarly, Streptomyces olivochromogenes FAE showed activity against methyl ferulate, methyl sinapinate and methyl p-coumarate, but at a level 420 -fold less (on methyl ferulate) than the A. niger esterase. No activity was detected against the benzoate methyl esters. For both enzymes, this shows the necessity for C-3 on the phenol ring to be methoxylated and the aliphatic region of the substrate to be unsaturated. The specific activity of FAE-III on destarched wheat bran was $31 \mathrm{U}$ (mg protein) ${ }^{-1}$ in the presence of Trichoderma viride xylanase and $3 \mathrm{U}$ (mg protein $)^{-1}$ in the absence. Apparent pH dependent binding of $A$. niger FAE-III to microcrystalline cellulose was also demonstrated.

Keywords: Aspergillus niger, ferulic acid esterase, xylanase, Streptomyces olivocbromogenes

\section{INTRODUCTION}

Plant cell wall polysaccharides are degraded by microorganisms provided they produce the necessary enzymes. The more complex the polymer, the greater the number of enzymes required, in most cases, to degrade it. Polysaccharide-degrading enzymes act synergistically to achieve total bioconversion of cell wall material whether they exist as a multi-enzyme complex, as with the Clostridium thermocellum cellulosome (Lamed \& Bayer, 1988 ), or as individual enzymes interacting with each

Abbreviations: FAE, Ferulic acid esterase; MCA, methyl caffeate (3,4-dihydroxycinnamate); MCC, microcrystalline cellulose; MdMCA, methyl 3,4-dimethoxycinnamate; MFA, methyl ferulate (3-methoxy-4hydroxycinnamate); MpCA, methyl $p$-coumarate (4-hydroxycinnamate); MSA, methyl sinapinate (3,5-dimethoxy-4-hydroxycinnamate); MSyA, methyl syringate (3,5-dimethoxy-4-hydroxybenzoate); MVA, methyl vanillate (3-methoxy-4-hydroxybenzoate). other. Groups of enzymes are arranged into 'systems', such as xylan-degrading (Tuohy et al., 1993; Myburgh et al., 1991; Johnson et al., 1988) and cellulose-degrading (Beguin et al., 1992; Wood, 1992). The nature of these enzyme-substrate interactions and cooperativity between enzymes are presently the subject of extensive research, especially concerning the breakdown of cellulose and hemicellulose (Gilbert \& Hazlewood, 1993), because of possible exploitation in agricultural and industrial processes (Gilbert \& Hazlewood, 1991).

Complex polysaccharides, such as the arabinoxylans of wheat bran (Smith \& Hartley, 1983), barley straw (Mueller-Harvey et al., 1986), maize (Kato \& Nevins, 1985) and sugar-cane bagasse (Kato et al., 1983), and the pectins of sugar beet (Rombouts \& Thibault, 1986) and spinach (Fry, 1982) are highly branched and require a battery of enzymes to break down the polymer. A further complication in the hydrolysis of these polysaccharides 
occurs when some sugar residues are esterified to phenolic compounds, such as ferulic and $p$-coumaric acids. These phenolic acids limit the digestibility of the plant cell wall material by microbes and can even be toxic to growth (Borneman et al., 1986; Chesson et al., 1982; Jung \& Sahlu, 1986). Only a few species have been reported to produce esterases which cleave the phenolic compounds from the sugar moiety, leaving the remainder of the polysaccharide open for further hydrolytic attack by other enzymes. Recently, these esterases have been purified and partially characterized from Streptomyces olivochromogenes (Faulds \& Williamson, 1991, 1993a), Neocallimastix (Borneman et al., 1991, 1992), Pseudomonas fluorescens (Ferreira et al., 1993), Penicillium pinophilum (Castanares et al., 1992) and several from Aspergillus (Tenkanen $e t$ al., 1991; Faulds \& Williamson, 1993b). The specificities of the enzymes for methyl esters of cinnamic acids, acting as model substrates, show that the Pseudomonas esterase and two isoforms from Aspergillus niger (Faulds \& Williamson, 1993b) are specific for compounds with different substitutions on the phenolic ring of the cinnamic acid. Furthermore, these enzymes could not hydrolyse methyl esters of the benzoic acids (vanillate and syringate) showing the importance of the $\mathrm{C}=\mathrm{C}$ bond in the recognition of substrates.

The Pseudomonas esterase has been sequenced and shown to contain a cellulose-binding domain located at the $\mathrm{N}$ terminus (Ferreira et al., 1993). This enzyme did not bind to xylan. The cellulose binding domain exhibited almost complete homology with the corresponding regions of a xylanase and an arabinofuranosidase, and is related to the cellulose binding domain of the cellulases from the same organism (Ferreira et al., 1991, 1993). Fungal cellobiohydrolases also contain a cellulose binding domain (Tomme et al., 1988; Ong et al., 1989) but there have been no reports of non-cellulase enzymes containing a cellulose binding domain in fungi, unlike the bacterial ferulic acid esterase of $P$. fluorescens.

In this paper, we report the isolation, purification and characterization of an inducible ferulic acid esterase from Aspergillus niger CBS 120.49, which we have called FAEIII, as the activities and properties differ from FAE-I and -II from A. niger (Faulds \& Williamson, 1993b). The specificity for methyl esters of cinnamic and benzoic acids are discussed and compared to the specificity of $S$. olivochromogenes FAE. We also show that FAE-III is able to bind to microcrystalline cellulose.

\section{METHODS}

Growth of $\boldsymbol{A}$. niger. $A$. niger CBS 120.49 was grown as described by Archer et al. (1990), without the addition of peptone and Casamino acids. Carbon sources were added to this Aspergillus Minimum Medium as described in Results. Cultures, containing approximately $10^{6}$ spores per $100 \mathrm{ml}$ medium, were incubated at $25^{\circ} \mathrm{C}$ and shaken at 150 r.p.m. in $250 \mathrm{ml}$ Erlenmeyer flasks, containing $100 \mathrm{ml}$ medium, over a $4 \mathrm{~d}$ period.

Purification of FAE-III. 1. Ammonium sulphate precipitation. Culture filtrate, obtained by filtering through muslin, was subjected to $50 \%$ and $80 \%$ saturation $\left(\mathrm{NH}_{4}\right)_{2} \mathrm{SO}_{4}$ fractionation.
2. Hydrophobic interaction chromatography. The $80 \%$ pellet was resuspended in $50 \mathrm{mM}$ sodium phosphate $(\mathrm{pH} 7) / 1 \mathrm{mM}$ EDTA/0.6 M $\left(\mathrm{NH}_{4}\right)_{2} \mathrm{SO}_{4}$, syringe filtered, and fractionated on an FPLC hydrophobic interaction chromatography column (Phenyl-Superose, Pharmacia) as described previously (Faulds \& Williamson, 1991). Fractions of $0.5 \mathrm{ml}$ were collected. Aliquots of the pooled active fractions in $0.6 \mathrm{M}\left(\mathrm{NH}_{4}\right)_{2} \mathrm{SO}_{4}$ (2 ml) were reloaded, and fractions of $0.5 \mathrm{ml}$ were collected.

3. Anion-exchange chromatography. Pooled active fractions from the second hydrophobic interaction chromatography column, after buffer exchange using a Sephadex G-25 PD-10 column (Pharmacia) into $20 \mathrm{mM}$ Tris/ $\mathrm{Cl}$ (pH 8.8), were further fractionated on an anion-exchange chromatography column (Mono Q, Pharmacia), under conditions previously described (Faulds \& Williamson, 1993b). Fraction of $0.5 \mathrm{ml}$ were collected.

Enzyme assays. FAE activity was measured against methyl ferulate (MFA), methyl sinapinate (MSA), methyl $p$-coumarate (MPCA), methyl caffeate (MCA), methyl vanillate (MVA) and methyl syringate (MSyA) as described previously (Faulds \& Williamson, 1993b). Release of the cinnamic acids was monitored at $310 \mathrm{~nm}$ and at $280 \mathrm{~nm}$ for the benzoic acids. Activity against methyl-3,4-dimethoxycinnamic acid (MdMCA) was monitored by a change in absorbance at $335 \mathrm{~nm}$ using a Beckman DU-70 thermostated spectrophotometer under the same conditions as the HPLC assay. The spectrophotometric technique utilizes the relative differences at $\mathrm{pH} 6$ of the absorbance at $335 \mathrm{~nm}$ between the free acid and the corresponding methyl ester. The same method was used for the other methyl esters using estimated $\varepsilon$ values. Incubations for both spectrophotometer and HPLC assays were carried out at $37^{\circ} \mathrm{C}$. Activity on de-starched wheat bran was measured both in the absence and in the presence of $2 \mathrm{U}$ Trichoderma viride xylanase [Megazyme (Aust) Pty Ltd] as described previously (Faulds \& Williamson, 1991). Xylanase activity was detected using standard methodology by determining the release of reducing sugar (Miller, 1959) from $1 \%(\mathrm{w} / \mathrm{v}$ ) soluble oat spelt xylan (Kellet et al., 1990), and was expressed as xylose equivalents: one unit of enzyme activity released $1 \mu \mathrm{mol}$ sugar $\min ^{-1}$ at $37^{\circ} \mathrm{C}, \mathrm{pH} 6.5$. Acetylesterase and acetylxylan esterase activity were determined as described previously (Faulds \& Williamson, 1993b). One unit of enzyme released $1 \mu \mathrm{mol}$ product $\mathrm{min}^{-1}$ under the relevant assay conditions for all the enzyme activities measured. Protein was estimated using the Coomassie Protein Assay Reagent from Pierce.

$\boldsymbol{M}_{\mathrm{r}}$ determination. SDS-PAGE was performed using a Pharmacia PhastSystem by the method of Laemmli (1970), using a $12.5 \%(\mathrm{w} / \mathrm{v})$ homogeneous PhastGel. Gels were run in accordance with the optimized method for a homogeneous SDS-PAGE gel given in the manufacturer's techniques file no. 111. Samples, extensively dialysed against distilled water, freezedried and subsequently resuspended in distilled water, were loaded using applicator strips, and protein bands were determined by Coomassie staining. $M_{\mathrm{r}}$ values were estimated from a plot of $\log M_{\mathrm{r}}$ versus mobility using the following standards: bovine serum albumin (66000), egg albumin (45000), glyceraldehyde-3-phosphate dehydrogenase $(36000)$, carbonic anhydrase (29000), trypsinogen (24000), trypsin inhibitor (20100) and $\alpha$-lactalbumin (14200).

Gel filtration. Pooled active fractions from the second hydrophobic interaction chromatography column were also fractionated on an FPLC gel filtration column (Superose 6, Pharmacia), previously equilibrated with $50 \mathrm{mM}$ sodium phosphate $/ 0 \cdot 15 \mathrm{M}$ $\mathrm{NaCl}(\mathrm{pH} 7)$, and calibrated with a MW-GF-200 kit (Sigma). Fractions of $0.2 \mathrm{ml}$ were collected. 
Ferulic acid<smiles>COc1cc(C=CC(=O)O)ccc1O</smiles>

p-Coumaric acid<smiles>O=C(O)C=Cc1ccc(O)cc1</smiles>

Sinapinic acid<smiles>COc1cc(C=CC(=O)O)cc(OC)c1O</smiles><smiles>COc1cc(C(=O)O)ccc1O</smiles>

Vanillic acid<smiles>O=C(O)C=Cc1ccc(O)c(O)c1</smiles>

Caffeic acid<smiles>COc1cc(C(=O)O)cc(OC)c1O</smiles>

Syringic acid<smiles>COc1ccc(C=CC(=O)O)cc1OC</smiles>

3,4-Dimethoxycinnamic acid

Fig. 1. Structures of the seven phenolic acids used in the present investigation.

Isoelectric point determination. The $\mathrm{pI}$ of FAE-III was determined by the method described previously (Faulds \& Williamson, 1993b). Samples, extensively dialysed against water, were loaded using 6/4 applicator strips (Pharmacia). Gels were fixed and the protein bands visualized by Coomassie staining. pI values were determined from a plot of migration distance versus $\mathrm{pI}$ values of the following standards: patent blue (VF) sodium salt $(2 \cdot 4)$, glucoamylase $(3 \cdot 65)$, acetylated cytochrome $C(3.95)$, glucose oxidase $(4 \cdot 25)$, C. phytocyanin $(4.75$ and 4.85$), \beta$-lactoglobulin A (5.25), $\beta$-lactoglobulin B (5.35) and azurin (5.65), obtained from BDH ('Electran' pI calibration kit, range $2 \cdot 4-5 \cdot 65)$.

Enzyme kinetics. Enzyme was incubated with 0-1.2 mM MFA, $0-1.2 \mathrm{mM}$ MdMCA or $0-3 \mathrm{mM}$ MSA for $15 \mathrm{~min}$ at $37^{\circ} \mathrm{C}$, and free acid determined as a change at $335 \mathrm{~nm}$ on a Beckman DU-70 spectrophotometer. Data were analysed by the method of Wilkinson (1961).

Temperature optimum. FAE-III was incubated with $0.94 \mathrm{mM}$ MFA over a temperature range of $20-70^{\circ} \mathrm{C}$. The optimum temperature was calculated from the total $\mu \mathrm{mol}$ product released after a $30 \mathrm{~min}$ incubation, as described in the assay procedure (Faulds \& Williamson, 1991).

pH optimum. FAE-III was incubated with $0.94 \mathrm{mM}$ MFA in $100 \mathrm{mM}$ McIlvaine buffer over the $\mathrm{pH}$ range $3 \cdot 0-7 \cdot 0$ and in $100 \mathrm{mM}$ phosphate buffer over the $\mathrm{pH}$ range $7 \cdot 0-8.0$ in 0.5 unit increments. The $\mathrm{pH}$ optimum was calculated as for the temperature optimum.

Preparation of the methyl esters. Methyl derivatives of the phenolic acids shown in Fig. 1 were prepared by the method of Borneman et al. (1990). The absorption spectrum of each derivative was compared in dilute $\mathrm{NH}_{3}(\mathrm{pH} 10)$, MOPS ( $\left.\mathrm{pH} 6\right)$ and dilute acetic acid ( $\mathrm{pH} 3$ ), with that of the free acid to check its purity (Fry, 1982). The absorption coefficient of each compound was calculated from these values using the BeerLambert law.

The absorbance maxima $(\lambda)$ and absorbance coefficient $(\varepsilon)$ values for each methyl ester compound and its corresponding free acid (Fig. 1) at three $\mathrm{pH}$ values are given in Table 1 . The values for ferulic acid, methyl ferulate and $p$-coumaric acid at $\mathrm{pH} 3$ and 10 are similar to the values obtained by Fry (1982). From this table, a measurement of the rate of hydrolysis at $\mathrm{pH} 6$ may be obtained as a change in absorbance at a determined wavelength. This measurement is dependent on the $\mathrm{pH}$ values of the substrate and the $\mathrm{pH}$ range of the enzyme. For purified $S$. olivocbromogenes FAE, this was determined to be $5 \cdot 5$ (Faulds \& Williamson, 1991). Hatfield et al. (1991) used a spectrophotometric method to measure FAE activity from some commercially available preparations using a chemically synthesized substrate (methyl 5$O$-trans-feruloyl- $\alpha$-L-arabinofuranoside). By altering the $\mathrm{pH}$ at the end of a $20 \mathrm{~min}$ incubation at $25^{\circ} \mathrm{C}$ from $\mathrm{pH} 8$ to $\mathrm{pH} 11.5$, a shift in absorbance at $375 \mathrm{~nm}$ was measured. By using this method, the absorbance difference between a free acid and its methyl ester could be measured for the esters prepared in this study. However, as $S$. olivocbromogenes FAE activity was lost above $\mathrm{pH} 7 \cdot 5$, it is not suitable for all enzymes. A measurement at a lower $\mathrm{pH}$ would be more desirable. At $335 \mathrm{~nm}$, the spectral differences between the free acid and the corresponding methyl ester allow direct measurements to be made, and at $\mathrm{pH} \mathrm{6,} \mathrm{the}$ enzymes are active.

To check the purity of the methyl esters, ${ }^{1} \mathrm{H}-\mathrm{NMR}$ spectra were recorded on a Hitachi R-200 Rapid Scan Correlation (Gupta et al., 1974) NMR spectrophotometer (Nissei Sangyo Co. Ltd) at $60 \mathrm{MHz}$. All samples were dissolved in $1 \mathrm{ml}$ of $\mathrm{D}_{2} \mathrm{O}$ /acetone $\mathrm{d}_{6}$ $(1: 1, \mathrm{v} / \mathrm{v})$ at a concentration of approximately $5 \mathrm{mM}$. A 
Table 1. Comparison of the absorption maximum $(\lambda)$ and absorption coefficient $(\varepsilon)$ for each phenolic acid and its methyl ester at three $\mathrm{pH}$ values

pH 3, dilute acetic acid; pH 6, 100 mM MOPS buffer; pH 10, dilute ammonia.

\begin{tabular}{|c|c|c|c|c|c|c|}
\hline \multirow[t]{2}{*}{ Phenolic compound } & \multicolumn{2}{|c|}{$\mathrm{pH} 3 \cdot 0$} & \multicolumn{2}{|c|}{ pH 6.0 } & \multicolumn{2}{|c|}{ pH 10.0 } \\
\hline & $\lambda_{\max }(\mathrm{nm})$ & $\varepsilon\left(\mathrm{M}^{-1} \mathrm{~cm}^{-1}\right)$ & $\lambda_{\max }(\mathrm{nm})$ & $\varepsilon\left(\mathbf{M}^{-1} \mathrm{~cm}^{-1}\right)$ & $\lambda_{\max }(\mathrm{nm})$ & $\varepsilon\left(\mathbf{M}^{-1} \mathrm{~cm}^{-1}\right)$ \\
\hline Ferulic acid & 320 & 17000 & 310 & 15900 & 343 & 22400 \\
\hline Methyl ferulate & 322 & 49000 & $321 \cdot 5$ & 27500 & 369 & 35500 \\
\hline$p$-Coumaric acid & 308 & 20000 & 285 & 17800 & 331 & 18600 \\
\hline Methyl coumarate & 309 & 58900 & 310 & 23400 & 353 & 35500 \\
\hline Sinapinic acid & $320 \cdot 5$ & 11500 & 306 & 12900 & $354 \cdot 5$ & 12600 \\
\hline Methyl sinapinate & $321 \cdot 5$ & 19100 & $321 \cdot 5$ & 18200 & $382 \cdot 5$ & 24000 \\
\hline Caffeic acid & 321 & 18200 & 286 & 14500 & 341 & 15800 \\
\hline Methyl caffeate & 323 & 41700 & $322 \cdot 5$ & 25100 & 365 & 43700 \\
\hline 3,4-Dimethoxycinnamic acid & $318 \cdot 5$ & 8100 & 309 & 8100 & 285 & 7600 \\
\hline Methyl dimethoxycinnamic acid & $320 \cdot 5$ & 69200 & $320 \cdot 5$ & 75900 & $320 \cdot 5$ & 66100 \\
\hline Vanillic acid & 260 & 11000 & 251 & 9800 & 294 & 12300 \\
\hline Methyl vanillate & 261 & 12300 & 261 & 12000 & 312 & 20000 \\
\hline Syringic acid & 273 & 11200 & $261 \cdot 5$ & 12000 & 312 & 20000 \\
\hline Methyl syringate & 274 & 9100 & 274 & 10200 & 322 & 13800 \\
\hline
\end{tabular}

10 p.p.m. scan width was used with a sweep rate of $20 \mathrm{~s} ; 10$ scans were co-added before correlation. The HOD peak at $5 \cdot 1$ p.p.m. was used as an internal standard. The methyl esters were compared to the published spectra of the free acids (The Aldrich Library of NMR Spectra, 1974), and the methoxy peak confirmed synthesis of the methyl esters.

Binding studies. FAE-III (approx. $40 \mathrm{U}$ ) was incubated with 0-100 mg microcrystalline cellulose (MCC; Sigmacell, Type 20; Sigma) $\mathrm{ml}^{-1}$ at $4{ }^{\circ} \mathrm{C}$ using a thermostatically controlled rotating incubator, for $2 \mathrm{~h}$ at various $\mathrm{pH}$ values. Samples were then centrifuged at 10000 r.p.m. for $10 \mathrm{~min}$ and the supernatant assayed for remaining FAE activity.

S. olivochromogenes FAE. Ferulic acid esterase from $S$. olivochromogenes was purified as described previously (Faulds \& Williamson, 1991). Assays were carried out at $50^{\circ} \mathrm{C}$ with $0.94 \mathrm{mM}$ substrates in $100 \mathrm{mM}$ MOPS ( $\mathrm{pH}$ 6).

\section{RESULTS}

\section{Inducibility of FAE-III}

A. niger CBS 120.49 was grown on Aspergillus Minimum Medium containing 1\%(w/v) glucose, $1 \%(\mathrm{w} / \mathrm{v})$ oat spelt xylan or $0.1 \%$ glucose $/ 1 \%$ xylan. Samples of the medium were removed every 24 h over a $4 \mathrm{~d}$ incubation and assayed for FAE and xylanase activity (Fig. 2). Xylanase was produced by the fungus under all three growth conditions, levels of activity increasing with incubation time. Onset of activity appeared to be delayed $24 \mathrm{~h}$ when xylan/glucose served as the carbon source. Highest activity was recorded after $4 \mathrm{~d}$ growth when glucose alone served as the carbon source. Ferulic acid esterase activity was also detected under all three con- ditions, but the level of activity was clearly dependent upon the carbon source. When $1 \%$ glucose or xylan alone served as the carbon source, activity was detected after $48 \mathrm{~h}$ incubation, but then decreased. Activity in the xylan cultures was 10 -fold higher than that in the glucose cultures. In the xylan/glucose-grown cultures, FAE activity was produced after $72 \mathrm{~h}$ growth, simultaneously with xylanase, and levels increased over time. This appeared to be the most suitable carbon source for FAE production.

The fungus was also grown for $4 \mathrm{~d}$ on mixtures of plant cell wall material and glucose $(0 \cdot 1 \%)$. Highest activity $\left.[1.25 \mathrm{U} \text { (mg protein })^{-1}\right]$ was recorded when oat spelt xylan $(1 \%)$ served as the second carbon source. When grown on wheat bran $(4 \%) /$ distillers spent grain $(1 \%)$, orange peel pectin $(1 \%)$ and sugar beet pulp $(4 \%)$, specific activities of $0.44,0.01$ and $0.005 \mathrm{U}$ (mg protein) ${ }^{-1}$, respectively, were obtained. These results show that the carbon source clearly influences the induction of FAE from $A$. niger and that FAE and xylanase expression are not under the same control.

\section{Purification of FAE-III}

Table 2 summarizes a typical purification of FAE-III from $A$. niger. The esterase was purified from material secreted into the medium by the fungus. Note all the oat spelt xylan was degraded by the fungus during growth. Nonsolubilized substrate was centrifuged as a brown pellet along with protein after addition of $\left(\mathrm{NH}_{4}\right)_{2} \mathrm{SO}_{4}$ to $50 \%$ saturation. The resuspended pellet from this step was recentrifuged and both the resulting (second) pellet and the 


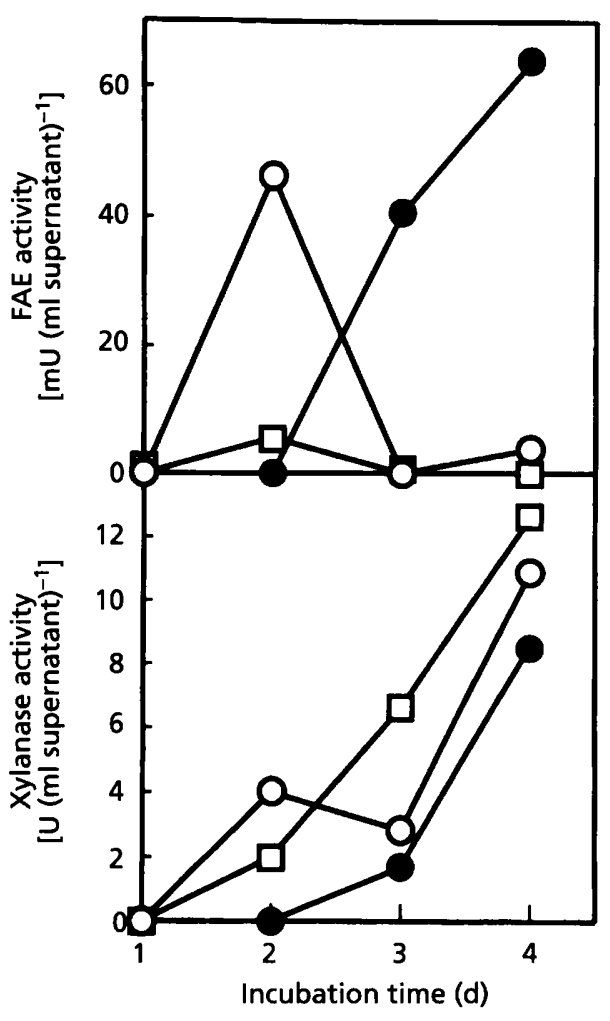

Fig. 2. Induction of FAE-III and xylanase from A. niger CBS 120.49 grown on Aspergillus Minimum Medium (see Methods) with added carbon source. FAE activity was measured using methyl ferulate. $O$, Oat spelt xylan $(1 \%, w / v) ; \square$, glucose $(1 \%$, $w / v) ; 0$, oat spelt xylan $(1 \%)+$ glucose $(0.1 \%)$.

clear supernatant exhibited FAE activity, but at very low levels compared to the initial pellet (results not shown). The location of the remaining activity has yet to be determined.

The pellet, after $80 \%\left(\mathrm{NH}_{4}\right)_{2} \mathrm{SO}_{4}$ saturation, was then subjected to hydrophobic interaction chromatography. The enzyme eluted as a single active peak between 68 and
$34 \mathrm{mM}$ ammoniurn sulphate (not shown). This peak was rechromatographed. On the second hydrophobic interaction chromatography step, activity coincided with the sole $A_{280}$ peak. After anion-exchange (Mono Q), FAE-III eluted as a single sharp peak between 0.37 and $0.42 \mathrm{M} \mathrm{KCl}$ (not shown), giving a final purification of 26 -fold and an apparent yield of $117 \%$ activity using methyl ferulate. This high yield may signify the removal of an inhibitory factor. The second peak on the anion-exchange column had no FAE activity associated with it and contained no protein as shown using the Coomassie Protein Assay reagent. It was possibly low molecular mass material, as found after gel filtration, since the absorption maxima (at $260 \mathrm{~nm}$ ) were identical.

\section{Properties of FAE-III}

FAE-III was stable for at least 2 months at $4{ }^{\circ} \mathrm{C}$ after hydrophobic interaction chromatography. Stability after further purification was not examined. On SDS-PAGE, FAE-III eluted as a band corresponding to $M_{\mathrm{r}}=36000$ (not shown). There was also a very faint band at $M_{\mathrm{r}} \sim 33000$.

On gel filtration, FAE-III, after the second hydrophobic interaction chromatography step, eluted as a single active peak correlating to $M_{\mathrm{r}}=14500$ ( \pm 2300 ) (not shown), which is lower than the value obtained by SDS-PAGE. Retardation of FAE-III on the gel filtration column was also observed for $S$. olivochromogenes FAE (Faulds \& Williamson, 1991). As the $M_{\mathrm{r}}$ of the native and the denatured enzyme differ, it is not possible to estimate the number of subunits associated with FAE-III. An absorption spectrurn of FAE-III after gel filtration showed that there was a peak at $280 \mathrm{~nm}$, with no additional chromophores. After gel filtration, a large peak was separated which showed no FAE activity, perhaps similar to the peak on the anion-exchange column. The spectrum of this peak exhibited $\lambda_{\max }=260 \mathrm{~nm}$ and did not react in the Coomassie Protein Assay.

FAE-III has an isoelectric point of 3.3. No other bands were observed. This value is in the pI range of other

Table 2. Purification of FAE-III from A. niger as measured by MFA hydrolysis

\begin{tabular}{|c|c|c|c|c|c|}
\hline Step & $\begin{array}{l}\text { Vol. } \\
(\mathrm{ml})\end{array}$ & $\begin{array}{l}\text { Specific activity } \\
{\left[\mathbf{U}(\mathrm{mg} \text { protein })^{-1}\right]}\end{array}$ & $\begin{array}{c}\text { Total } \\
\text { activity } \\
\text { (U) }\end{array}$ & $\begin{array}{l}\text { Purification } \\
\text { (-fold) }\end{array}$ & $\begin{array}{l}\text { Yield } \\
(\%)\end{array}$ \\
\hline Crude culture supernatant & 890 & $2 \cdot 6$ & 239 & 1 & 100 \\
\hline $50 \%$ ammonium sulphate & 20 & ND & 58 & ND & 24 \\
\hline $80 \%$ ammonium sulphate & 20 & ND & 165 & ND & 69 \\
\hline 1. 1st hydrophobic interaction & 40 & 28 & 104 & $10 \cdot 6$ & 43 \\
\hline 2. 2nd hydrophobic interaction & 60 & 36 & 82 & $13 \cdot 7$ & 34 \\
\hline 3. Anion-exchange & 63 & 67 & 279 & $25 \cdot 7$ & 117 \\
\hline Supernatant from ammonium sulphate & 1110 & ND & $3 \cdot 2$ & ND & $1 \cdot 3$ \\
\hline
\end{tabular}

ND, Not determined. 
Table 3. Specificity of FAE-III for methyl esters of phenolic acids. Values in parentheses are \pm SD.

\begin{tabular}{|lcccc|}
\hline Substrate & $\begin{array}{c}\text { Specific activity } \\
{\left[\mathbf{U}(\mathbf{m g} \text { protein })^{-1}\right]}\end{array}$ & $\begin{array}{c}\boldsymbol{K}_{\mathbf{m}} \\
(\mathbf{m M})\end{array}$ & $\begin{array}{c}\boldsymbol{V}_{\text {max }} \\
{\left[\mathbf{U}(\mathbf{m g} \text { protein) })^{-1}\right]}\end{array}$ & $\boldsymbol{V}_{\text {max }} / \boldsymbol{K}_{\mathbf{m}}$ \\
\hline MFA & $67 \cdot 2$ & $2 \cdot 08(0 \cdot 19)$ & $175(14)$ & $84 \cdot 1$ \\
MVA & - & ND & ND & ND \\
MpCA & $0 \cdot 07$ & ND & ND & ND \\
MSA & 156 & $1 \cdot 44(0 \cdot 36)$ & $286(34)$ & 199 \\
MSyA & - & ND & ND & ND \\
MCA & - & ND & ND & ND \\
MdMCA & 38.9 & $1 \cdot 36(0 \cdot 30)$ & $123(18)$ & $90 \cdot 4$ \\
\hline
\end{tabular}

, Not detected.

ND, Not determined.

Aspergillus esterases (3.0-3.8), and is the same as the major esterase previously identified, but not purified, from a wheat-grown culture of $A$. niger (McCallum et al., 1991).

The esterase has a temperature optimum between 55 and $60{ }^{\circ} \mathrm{C}$ on MFA. The standard assay temperature of $50^{\circ} \mathrm{C}$ (Faulds \& Williamson, 1993b) was changed to $37^{\circ} \mathrm{C}$ in this study, as $50{ }^{\circ} \mathrm{C}$ is probably too close to the temperature optimum to ensure stability of the enzyme over long incubations. A comparison of activities at both temperatures over each step of the purification revealed an average drop in activity of only $28 \%$ at the lower temperature (results not shown).

A pH optimum of 5.0 was obtained, with $50 \%$ of activity at $\mathrm{pH} 4$ and $6 \cdot 1$. This may be due to aspartic or glutamic acids $(\mathrm{pK} 4.4)$ in the deprotonated state, and histidine $(\mathrm{p} K 6.5)$ in the protonated state. Ferulic acid esterases isolated so far appear to have a range of $\mathrm{pH}$ optima, from 4.5-7.0; those from Aspergillus exhibit optimum activities in the more acidic range.

\section{Substrate specificity of $A$. niger and S. olivochromogenes FAE for phenolic acids}

Table 3 summarizes the specificity of FAE-III for the cinnamic acids. No hydrolysis of the benzoic acid esters occurred, showing the necessity for the $\mathrm{C}=\mathrm{C}$ on the aliphatic chain. The enzyme has a higher activity on MSA than on MFA or MdMCA. FAE-III has no activity on $\mathrm{MCA}$ and very little on MpCA, showing the necessity for $\mathrm{C}-3$ on the phenol ring to be methoxylated. Although an absence of substitution can be tolerated at C- 5 , the presence of a methoxy group increases the hydrolytic rate. Substitution at C-4 by a methoxy group does not influence catalysis. The specificity for cinnamic acid methyl esters of the $50 \%\left(\mathrm{NH}_{4}\right)_{2} \mathrm{SO}_{4}$ pellet was identical to the $80 \%$ pellet (FAE-III) suggesting only one isoenzyme.. This purification step, however, was required to remove undigested xylan from the enzyme preparation.

S. olivochromogenes FAE showed almost equal activity against MFA $\left[0 \cdot 16 \mathrm{U}(\mathrm{mg} \text { protein })^{-1}\right]$ and MSA $[0 \cdot 13 \mathrm{U}$ (mg protein $\left.)^{-1}\right]$ and very low activity against $\mathrm{MpCA}$ $\left.[0.003 \mathrm{U} \text { (mg protein })^{-1}\right]$. The difference in levels of activity between the fungal esterase and the bacterial esterase for MFA is 420 -fold, even though their substrate specificities are similar.

\section{Associated enzyme activities}

FAE-III from $A$. niger was assayed for associated hydrolytic activities. Xylanase activity was detected in FAEcontaining samples after the first hydrophobic interaction chromatography column [35 $\mathrm{U}$ (mg protein) $\left.{ }^{-1}\right]$, but no xylanase was detected after further purification. Three milliUnits of enzyme released $0.6 \%$ of ferulic acid from de-starched wheat bran after a $30 \mathrm{~min}$ incubation at $37^{\circ} \mathrm{C}$, assuming ferulic acid is $0.5 \%(\mathrm{w} / \mathrm{w})$ of the dry weight of wheat bran (Ralet et al., 1990), without the addition of

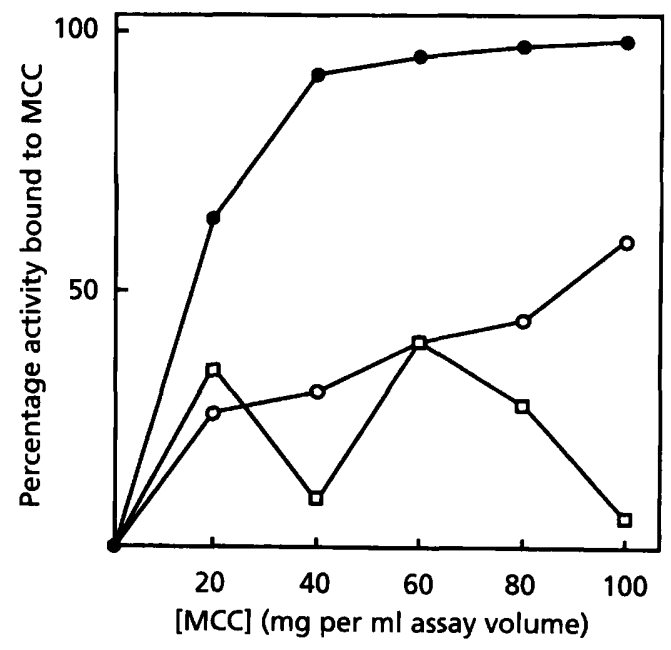

Fig. 3. Binding of FAE-III to microcrystalline cellulose (MCC) at different $\mathrm{pH}$ values. Activity is expressed as a percentage of activity bound to cellulose when compared to controls without cellulose under the same conditions., $50 \mathrm{mM}$ sodium acetate (pH 4); O, $100 \mathrm{mM}$ MOPS (pH 6); $\square, 50 \mathrm{mM}$ sodium phosphate $(\mathrm{pH} 7)$. 


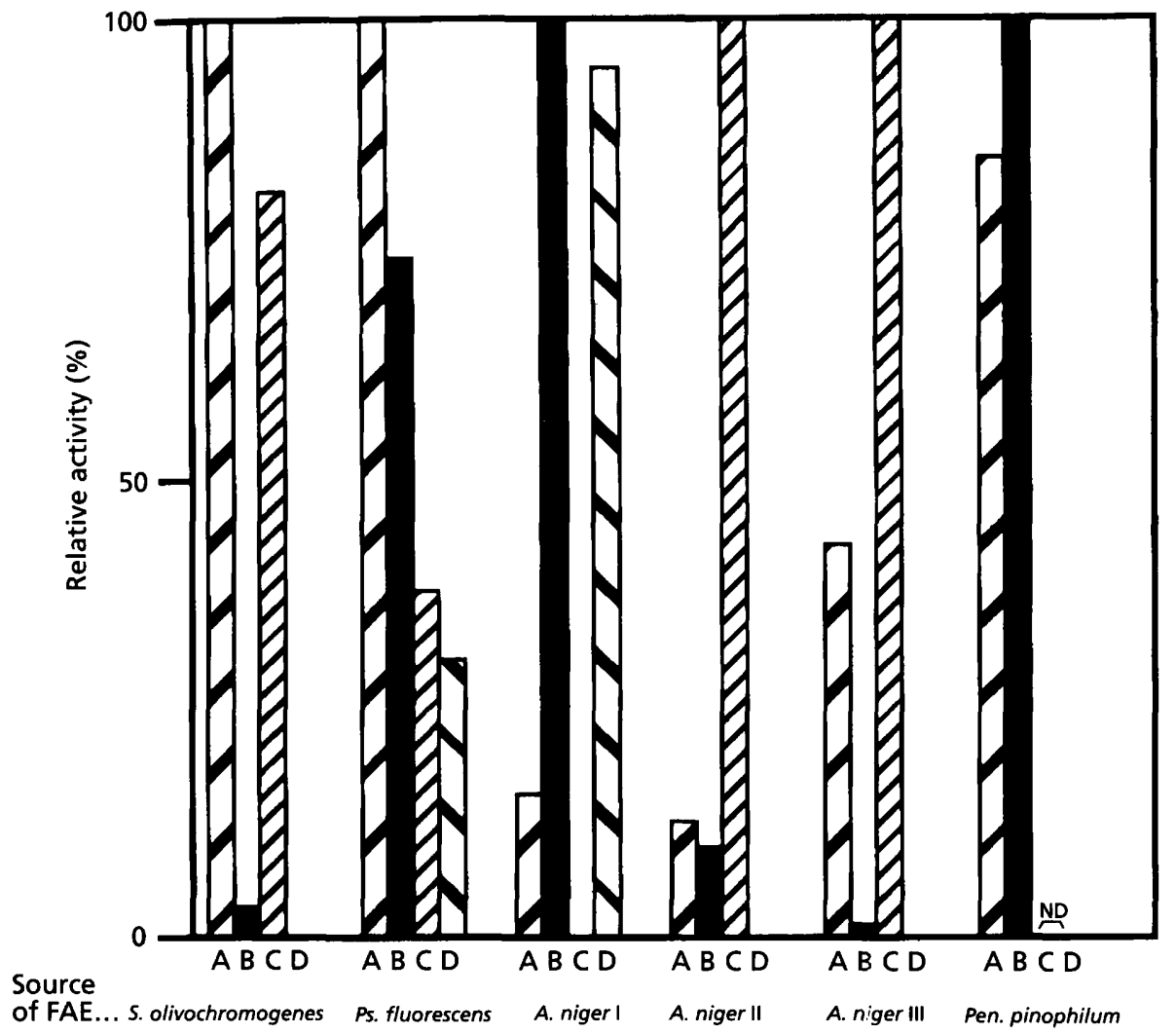

Fig. 4. Comparison of esterases with activity on MFA against methyl esters of cinnamic acids. A, Methyl ferulate; $B$, methyl $p$-coumarate; $C$, methyl sinapinate; $D$, methyl caffeate; ND, not determined.

xylanase. Upon the addition of $2 \mathrm{U} T$. viride xylanase (FAE free), the same amount of FAE-III released $6.6 \%$ of the total ferulic acid from de-starched wheat bran, an 11 fold increase in activity due to the synergistic interaction of the two enzymes. The specific activity of FAE-III on de-starched wheat bran was $31 \mathrm{U}$ (mg protein) ${ }^{-1}$ in the presence of $T$. viride xylanase and $3 \mathrm{U}(\mathrm{mg} \text { protein })^{-1}$ in the absence. This shows that FAE-III acts directly on plant cell wall material.

Upon acetylated xylan, without the addition of a xylanase, FAE-III had a specific activity of $4 \mathrm{U}$ (mg protein $)^{-1}$. Acetylesterase activity was measured as $93 \mathrm{U}$ (mg protein $)^{-1}$ on $p$-nitrophenyl acetate.

\section{Binding to microcrystalline cellulose}

As activity was apparently associated with the undigested xylan after the $0-50 \%\left(\mathrm{NH}_{4}\right)_{2} \mathrm{SO}_{4}$ cut (Table 2), even after washing with buffer, the possibility that FAE-III might bind to microcrystalline cellulose (MCC) was examined. On incubation at $4{ }^{\circ} \mathrm{C}$ with $\mathrm{MCC}$ in $50 \mathrm{mM}$ sodium acetate $(\mathrm{pH} 4)$ for $2 \mathrm{~h}$, FAE-III activity in the supernatant upon centrifugation was found to be related to the amount of MCC present (Fig. 3). This may be due to FAE-III binding to MCC: $91 \%$ of the activity was removed from the supernatant in the presence of $40 \mathrm{mg}$ MCC per ml assay mixture, and so the binding reaches saturation. The binding was $\mathrm{pH}$ dependent. The enzyme was not released from MCC after a $2 \mathrm{~h}$ incubation at room temperature in the presence of water.

\section{DISCUSSION}

Ferulic acid esterase from Aspergillus niger CBS 120.49 is inducible by growth on oat spelt xylan. We have already purified two ferulic acid esterases from $A$. niger which were present in a commercial preparation of pectinase (Faulds \& Williamson, 1993b); these we termed FAE-I and FAE-II. We therefore propose that the ferulic acid esterase described in this paper is termed FAE-III. Fig. 4 compares the specificities of these enzymes with ferulic acid esterases from Streptomyces olivochromogenes, Psuedomonas fuorescens and Penicillium pinophilum.

The two bacterial enzymes show highest activity on methyl ferulate, but otherwise are very different. The fungal enzymes show highest activity on methyl cinnamates other than methyl ferulate. The relative activities do not allow classification of ferulic acid esterases into particular classes.

However, when the relative specificities of $A$. niger FAEIII are compared to those of FAE-II, the pattern methyl sinapinate $>$ methyl ferulate $>$ methyl $p$-coumarate $>$ methyl caffeate is observed for both enzymes. Although the specific activity of FAE-II (Faulds \& Williamson, 
1993b) is lower than FAE-III, it is possible that FAE-II may be a proteolytically modified FAE-III, since the $M_{\mathrm{r}}$ of the former (29000) is lower than the latter (36000). This hypothesis awaits resolution.

Most ferulic acid esterases release the free acid from wheat bran only in the presence of a xylanase (Faulds \& Williamson, 1991, 1992, 1993b; Tenkanen et al., 1991; Ferreira et al., 1993). Some, however, are able to act on plant cell walls in the absence of a xylanase (Borneman et al., 1992; Faulds \& Williamson, 1993b; Castanares et al., 1992). FAE-III clearly fits into the latter category, and in fact has a substantial activity $\left(3 \mathrm{U} \mathrm{mg}^{-1)}\right.$ on de-starched wheat bran.

Bacterial plant cell wall degrading enzymes commonly contain a cellulose binding domain (see Henrissat, 1992, for a review). However, it is less common for fungal enzymes to possess this domain. Although it is usually cellulose-degrading enzymes that contain a cellulose binding domain, there are exceptions, such as two xylanases, an arabinofuranosidase and acetyl/ferulic acid esterase from $P$. fuorescens (Hazlewood \& Gilbert, 1992). Thus, FAE-III from $A$. niger appears to be a member of a very small number of non-cellulose degrading enzymes able to bind cellulose specifically.

In summary, a ferulic acid esterase (FAE-III) from A. niger CBS 120.49 was purified to homogeneity and partially characterized. It was specific for methyl esters of cinnamic acids methoxylated at $\mathrm{C}-3$ on the phenolic ring (ferulic, sinapinic, 3,4-dimethoxycinnamic and $p$-coumaric acid). It did not recognize methyl esters of caffeic, vanillic and syringic acids. The enzyme has a $\mathrm{pH}$ optimum of 5 , a temperature optimum between 55 and $60^{\circ} \mathrm{C}$, and released nitrophenol from nitrophenyl acetate. FAE-III has a specific activity of $31 \mathrm{U}(\mathrm{mg} \text { protein })^{-1}$ on de-starched wheat bran in the presence of $T$. viride xylanase and $3 \mathrm{U}(\mathrm{mg} \text { protein })^{-1}$ in the absence. FAE-III appears to bind to microcrystalline cellulose, and this binding is influenced by $\mathrm{pH}$.

\section{ACKNOWLEDGEMENTS}

We would like to thank Mr Brian Goodfellow for carrying out the NMR studies and Dr David Archer for the donation of the A. niger strain. We would also like to thank both the AFRC and the European Commission (Grant no. PL 920026) for funding.

\section{REFERENCES}

Archer, D. B., Jeenes, D. J., MacKenzie, D. A., Brightwell, G., Lambert, N., Lowe, G., Radford, S. E. \& Dobson, C. M. (1990). Hen egg white lysozyme expressed in, and secreted from, Aspergillus niger is correctly processed and folded. Bio/Technology 8, 741-745.

Beguin, P., Millet, J., Chauvaux, S., Salamitou, S., Tokatlidis, K., Navas, J., Fujino, T., Lemaire, M., Raynaud, O., Daniel, M.-K. \& Aubert, J.-P. (1992). Bacterial cellulases. Biocbem Soc Trans 20, $42-46$.

Borneman, W. S., Akin, D. E. \& Van Eseltine, W. P. (1986). Effect of phenolic monomers on ruminant bacteria. Appl Environ Microbiol 52, 1331-1339.

Borneman, W. S., Hardly, R. D., Morrison, W. H., Akin, D. E. \& Ljungdahl, L. G. (1990). Feruloyl and $p$-coumaroyl esterase from anaerobic fungi in relation to plant cell wall degradation. Appl Microbial Biotecbnol 33, 345-351.

Borneman, W. S., Ljungdahl, L. G., Hartley, R. D. \& Akin, D. E. (1991). Isolation and characterization of p-coumaroyl esterase from the anaerobic fungus Neocallimastix strain MC-2. Appl Environ Microbiol 57, 2337-2344.

Borneman, W. S., Ljungdahl, L. G., Hartley, R. D. \& Akin, D. E. (1992). Purification and partial characterization of two feruloyl esterases from the anaerobic fungus Neocallimastix strain MC-2. Appl Environ Microbiol 58, 3762-3766.

Castanares, A., McCrae, S. I. \& Wood, T. M. (1992). Purification and properties of a feruloyl $/ p$-coumaroyl esterase from the fungus Penicillium pinophilum. Enzyme Microb Technol 14, 875-884.

Chesson, A., Stewart, C. S. \& Wallace, R. J. (1982). Influence of plant phenolic acids on growth and cellulolytic activity of rumen bacteria. Appl Environ Microbiol 44, 597-603.

Faulds, C. B. \& Williamson, G. (1991). The purification and characterization of 4-hydroxy-3-methoxycinnamic (ferulic) acid esterase from Streptomyces olivochromogenes. J Gen Microbiol 137, 2339-2345.

Faulds, C. B. \& Williamson, G. (1992). Ferulic acid release from plant polysaccharides by specific esterases. In Xylans and Xylanases, Progress in Biotechnology 7, pp. 419-422. Edited by J. Visser, G. Beldman, M. A. Kusters-van Someren \& A. G. J. Voragen. Amsterdam: Elsevier.

Faulds, C. B. \& Williamson, G. (1993a). Release of ferulic acid from plant polysaccharides by ferulic acid esterase from Streptomyces olivochromogenes. Carbohydr Polym 21, 153-155.

Faulds, C. B. \& Williamson, G. (1993b). Ferulic acid esterase from Aspergillus niger: purification and partial characterization of two forms from a commercial source of pectinase. Biotechnol Appl Biochem 17, 349-359.

Ferreira, L. M. A., Hazlewood, G. P., Barker, P. J. \& Gilbert, H. J. (1991). The cellodextrinase from Pseudomonas fluorescens subsp. cellulosa consists of multiple functional domains. Biochem $J \mathbf{2 7 9}$, 793-799.

Ferreira, L. M. A., Wood, T. M., Williamson, G., Faulds, C. B., Hazlewood, G. P. \& Gilbert, H. J. (1993). A modular esterase from Pseudomonas fuorescens subsp. cellulosa contains a non-catalytic cellulose binding domain. Biochem J 294, 349-355.

Fry, S. C. (1982). Phenolic components of the primary cell wall. Biochem J 203, 493-504.

Gilbert, H. J. \& Hazlewood, G. P. (1991). Genetic modification of fibre digestion. Proc Nutr Soc 50, 173-186.

Gilbert, H. J. \& Hazlewood, G. P. (1993). Bacterial cellulases and xylanases. J Gen Microbiol 139, 187-194.

Gupta, R. D., Ferretti, J. A. \& Becker, E. D. (1974). Rapid scan Fourier transform NMR spectroscopy. J Mag Reson 13, 275-290.

Hatfield, R. D., Helm, R. F. \& Ralph, J. (1991). Synthesis of methyl 5-O-trans-feruloyl- $\alpha$-L-arabinofuranoside and its use as a substrate to access feruloyl esterase activity. Anal Biochem 194, 25-33.

Hazlewood, G. P. \& Gilbert, H. J. (1992). The molecular architecture of xylanases from Pseudomonas fuorescens subsp. cellulosa. In Xylans and Xylanases, Progress in Biotechnology 7, pp. 259-273. Edited by J. Visser, G. Beldman, M. A. Kusters-van Someren \& A. G. J. Voragen. Amsterdam: Elsevier.

Henrissat, B. (1992). Analysis of hemicellulases sequences. Relationship to other glycanases. In Xylans and Xylanases, Progress in Biotechnology 7, pp. 97-110. Edited by J. Visser, G. Beldman, M. A. Kusters-van Someren \& A. G. J. Voragen. Amsterdam: Elsevier.

Johnson, K. G., Harrison, B. A., Schneider, H., MacKenzie, C. R. \& 
Fontana, J. D. (1988). Xylan-hydrolysing enzymes from Streptomyces spp. Enzyme Microb Technol 10, 403-409.

Jung, H.-J. G. \& Sahlu, T. (1986). Depression of cellulose digestion by esterified cinnamic acids. J Sci Food Agric 37, 659-665.

Kato, Y. \& Nevins, D. J. (1985). Isolation and identification of $O-(5-$ $O$-feruloyl-L-arabinofuranosyl)-(1-3)-O- $\beta$-D-xylopy ranosyl-(1-3)xylopyranose as a component of Zea shoot cell walls. Carbobydr Res 137, 139-150.

Kato, Y., Azuma, J. \& Koshijima, T. (1983). A new feruloylated trisaccharide from bagasse. Chem Lett 137-140.

Kellet, L. E., Poole, D. M., Ferreira, L. M. A., Durrant, A. J., Hazlewood, G. P. \& Gilbert, H. J. (1990). Xylanase B and an arabinofuranosidase from Pseudomonas fiuorescens subsp. cellulosa contain identical cellulose-binding domains and are encoded by adjacent genes. Biochem J 272, 369-376.

Laemmli, U. K. (1970). Cleavage of structural proteins during the assembly of the head of bacteriophage T4. Nature 227, 680-685.

Lamed, R. \& Bayer, E. A. (1988). The cellulosome of Clostridium thermocellum. Adv Appl Microbiol 33, 1-46.

McCallum, J. A., Taylor, I. E. P. \& Towers, G. H. N. (1991). Spectrophotometric assay and electrophoretic detection of trans-feruloyl esterase activity. Anal Biochem 196, 360-366.

Miller, G. L. (1959). Use of dinitrosalicylic reagent for determination of reducing groups. Anal Chem 31, 426-428.

Mueller-Harvey, I., Hartley, R. D., Harris, P. J. \& Curzon, E. H. (1986). Linkage of $p$-coumaroyl and feruloyl groups to cell-wall polysaccharides of barley straw. Carbohydr Res 148, 71-85.

Myburgh, J., Prior, B. A. \& Kilian, S. G. (1991). Production of xylan-hydrolysing enzymes by Aureobasidium pullulans. $J$ Ferment Bioeng 72, 135-137.
Ong, E., Greenwood, J. M., Gilkes, N. R., Kilburn, D. G., Miller, R. C. \& Warren, R. A. J. (1989). The cellulose-binding domains of cellulases: tools for biotechnology. Trends Biotechnol 7, 239-243.

Ralet, M.-C., Thibault, J.-F. \& Della Valle, G. (1990). Influence of extrusion-cooking on the physico-chemical properties of wheat bran. J Cereal Sci 11, 249-259.

Rombouts, F. M. \& Thibault, J.-F. (1986). Feruloylated pectic substances from sugar-beet pulp. Carbobydr Res 154, 177-187.

Smith, M. M. \& Hartley, R. D. (1983). Occurrence and nature of ferulic acid substitution of cell-wall polysaccharides in graminaceous plants. Carkobydr Res 118, 65 80.

Tenkanen, M., Schuseil, J., Puls, J. \& Poutanen, K. (1991). Production, purification and characterization of an esterase liberating phenolic acids from lignocellulosics. J Biotechnol 18, 69-84.

Tomme, P., van Tilbeurgh, H., Pettersson, G., van Damme, J., Vanderkerchkove, J., Knowles, J., Teeri, T. \& Claeyssens, M. (1988). Studies of the cellulolytic system of Trichoderma reesei $\mathrm{QM}$ 9414: analysis of domain function in two cellobiohydrolases by limited proteolysis. Eur J Biochem 170, 575-581.

Tuohy, M. G., Puls, J., Claeyssens, M., Vrsanska, M. \& Coughlan, M. P. (1993). The xylan-degrading enzyme system of Talaromyces emersonii: novel enzyrnes with activity against aryl $\beta$-D-xylosides and unsubstituted xylans. Biochem J 290, 515-523.

Wilkinson, G. N. (1961). Statistical estimations in enzyme kinetics. Biochem J 80, 324-332.

Wood, T. M. (1992). Fungal cellulases. Biochem Soc Trans 20, 46-53.

Received 29 June 1993; revised 6 October 1993; accepted 15 November 1993. 